Brit. J. prev. soc. Med. (1967), 21, 7-16

\title{
PATTERNS OF RESPIRATORY ILLNESS IN SHEFFIELD INFANT SCHOOLCHILDREN
}

\author{
BY \\ J. E. LUNN, J. KNOWELDEN, AND A. J. HANDYSIDE \\ Department of Preventive Medicine and Public Health, Sheffield University
}

An increasing volume of evidence points to atmospheric pollution as an important factor in the causation of respiratory illnesses. Unfortunately studies of the effects of pollution on adults tend to be complicated by smoking habits, changes of occupation, changes of address, and changes in pollution levels over a period of years (Holland and Reid, 1965; Zeidberg, Prindle, and Landau, 1964). Some of these complicating factors may be eliminated by careful selection of the subjects for study. Fairbairn and Reid (1958), working with a sample of postmen, found that severe bronchitis causing permanent disablement and death was related to the frequency of fog, and, presumably, to the level of air pollution. Their data did not permit them to assess the relevance of smoking habits. Rosenbaum (1961), working with a sample of national service men, was able to correlate the incidence of respiratory disease with their home locality before call-up. He suggested that the most likely factors in the situation were a lower resistance in those from industrial areas of the country and the acquisition of infection on leave.

A recent study on children by Douglas and Waller (1966) indicated a direct relationship between air pollution and lower respiratory tract infections in both boys and girls. No association was found between upper respiratory tract infections and air pollution. An earlier study by Toyama and Tomono (1961) on 10 and 11-year-old schoolchildren indicated that a group living in a highly-polluted industrial area had significantly lower peak flow rates and F.E.V.0.5 (forced expiratory volume in half a second) measurements than a group living in an unpolluted rural area; F.V.C. (forced vital capacity) measurements were not significantly affected.

The main purpose of the present study was to compare respiratory illnesses amongst Sheffield children living in areas of the city with different atmospheric pollution levels. It was considered desirable to include objective data in the form of pulmonary ventilatory measurements and to eliminate as many complicating factors as possible by using a very young age group.

\section{Selection of the Study AREas}

Pollution levels in Sheffield vary enormously in different parts of the city, partly because of the siting of industry in the North and East relative to the prevailing South and South-west winds and partly because the city varies in altitude from less than 200 to over 1,000 feet above sea level. Information about pollution levels is readily available, since both the University Geography Department and the Local Health Authority run a large number of sampling stations. It was possible, therefore, to select areas with quite distinctive pollution levels and for the most part to use pollution readings applicable to the exact areas in which the children lived. The children selected for the study comprised the whole first year infant intake of eight local authority schools in four contrasting areas. The positions of these schools in the city are shown in the Figure and the relative pollution data in Tables I and II (overleaf).

GreENHILl AREA.-The two cleanest areas, Greenhill and Hemsworth (referred to as Greenhill in the Tables), were situated on the South side of Sheffield close to the Derbyshire border and subject to a prevailing wind coming across open countryside. The children examined from these areas were drawn entirely from post-war council houses and attended new schools situated close to their homes. At the start of the study no measurements of pollution 


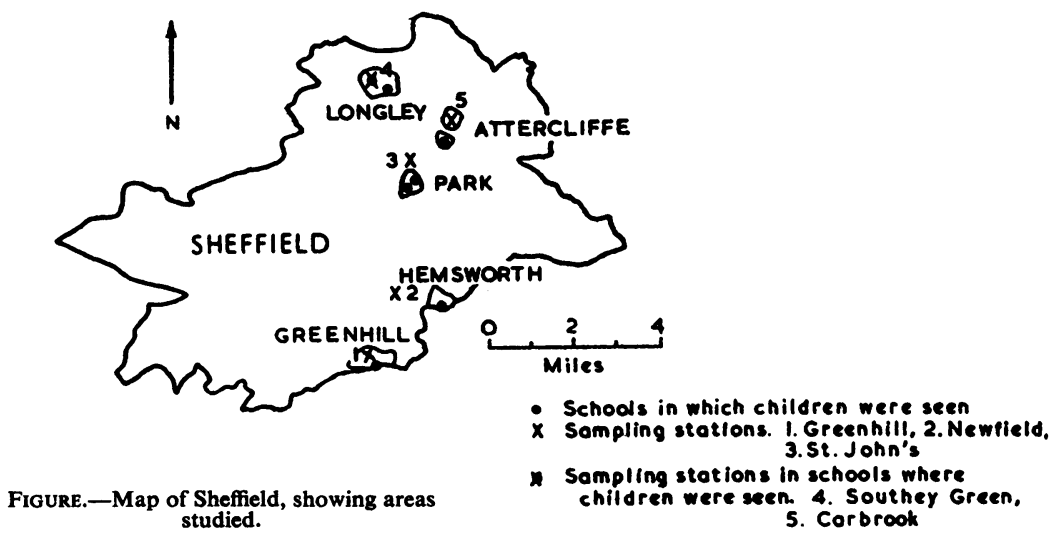

levels were available and the nearest sampling station was at Newfield school, situated closer to the city centre and at a considerably lower altitude. Because of this, it was suspected that the Newfield pollution readings would overestimate the pollution at Greenhill, and the subsequent establishment of a sampling station in the Greenhill School Clinic has confirmed this. Table II shows that Greenhill had lower pollution levels than Newfield over the Autumn, Winter, and Spring months (October-May) of 1965 and 1966. It is interesting that each sampling station shows mean daily pollution figures for the
Autumn, Winter, and Spring of $1965-6$ which are $>$ lower for smoke but higher for sulphur dioxide than the mean daily figures for the whole of 1964. Thesechanges may have been influenced by the rapido progress Sheffield is making in smoke control.

The pollution characteristics of the Greenhill area were smoke and sulphur dioxide mean daily figures $\vec{\theta}$ of about $100 \mu \mathrm{g} . / \mathrm{cu} . \mathrm{m}$. with no episodes in whichs daily figures exceeded $500 \mu \mathrm{g} . / \mathrm{cu} . \mathrm{m}$.

LONGLEY AREA.-The children examined in thits area attended two council schools, one of whichō

TABLE I

ATMOSPHERIC POLLUTION ( $\mu$ g./cu.m.) IN THE STUDY AREAS, 1964

\begin{tabular}{|c|c|c|c|c|c|c|c|c|c|}
\hline Area & $\cdots$ & $\cdots$ & $\cdots$ & $\cdots$ & $\cdots$ & Greenhill & Longley & Park & Attercliffe \\
\hline Pollution Station & $\cdots$ & $\cdots$ & $\ldots$ & . & $\cdots$ & Newfield School & Southey Green School & St. John's School & Carbrook School \\
\hline \multirow{2}{*}{\multicolumn{3}{|c|}{ Mean Daily Figures ( $\mu \mathrm{g} . / \mathrm{cu} . \mathrm{m})}}$. & Sm & & $\ldots$ & 97 & 230 & 262 & 301 \\
\hline & & & Sul & ur d & ide & 123 & 181 & 219 & 275 \\
\hline \multirow{2}{*}{\multicolumn{3}{|c|}{$\begin{array}{l}\text { Number of Days with Readings } \\
\text { over } 500 \mu \mathrm{g} . / \mathrm{cu} . \mathrm{m} \text {. }\end{array}$}} & Sm & & $\cdots$ & 4 & 30 & 40 & 45 \\
\hline & & & Sul & ur d & ide & 1 & 11 & 16 & 32 \\
\hline
\end{tabular}

TABLE II

ATMOSPHERIC POLLUTION ( $\mu$ g./cu.m.) IN THE STUDY AREAS AND THE GREENHILL SCHOOL CLINIC STATION OCTOBER, 1965-MAY, 1966, INCLUSIVE

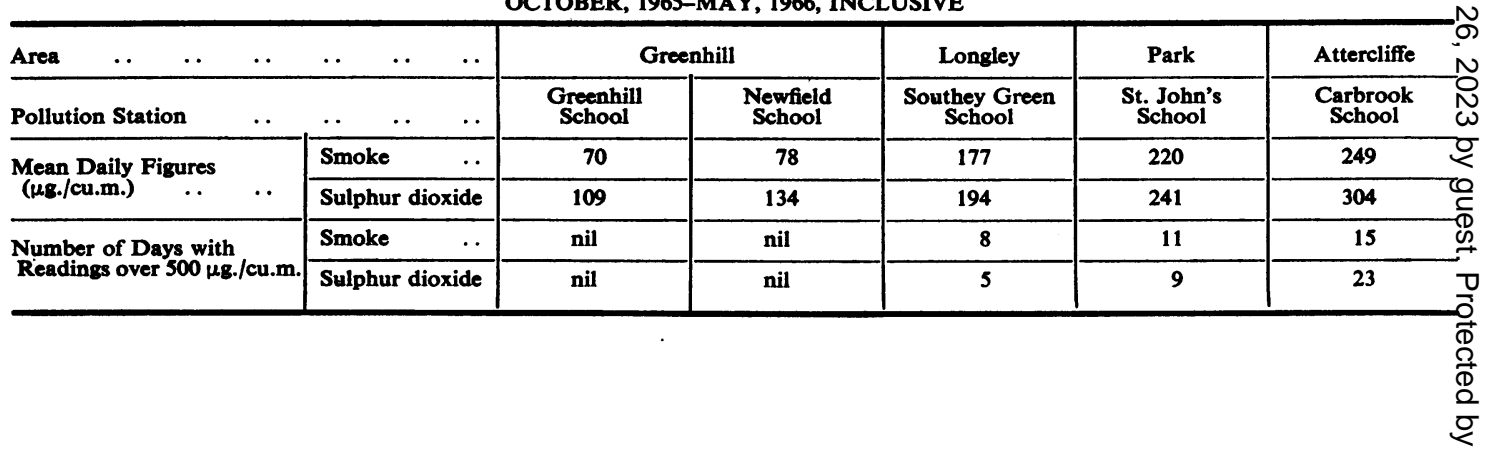


(Southey Green) also housed the sampling station. They were drawn entirely from pre-war council housing. Mean daily pollution levels (Tables I and II) were in the region of $200 \mu \mathrm{g}$./cu.m. of smoke or sulphur dioxide. Episodes in which daily figures exceeded $500 \mu \mathrm{g} . / \mathrm{cu} . \mathrm{m}$. were fairly common for smoke (thirty during 1964) but uncommon for sulphur dioxide (eleven during 1964).

Park Area.-The children examined attended two council schools in the area and came from a mixture of pre-war and post-war council flats. The sampling station for the area (St. John's School) lay several hundred yards to the north but at a similar altitude. Mean daily pollution levels (Tables I and II) were close to $250 \mu \mathrm{g}$./cu.m. for smoke and sulphur dioxide, and episodes in which daily figures exceeded $500 \mathrm{\mu g}$./cu.m. were common for smoke (forty during 1964) but still fairly uncommon for sulphur dioxide (sixteen during 1964).

ATterCliffe Area.-The two areas subject to the highest pollution levels were situated close together in the heavily-industrialized Don Valley region of the town. The children examined came from substandard Victorian terrace houses and attended two council schools, one of which (Carbrook School) also housed the sampling station. The mean daily pollution figures for 1964 (Tables I and II) were close to $300 \mu \mathrm{g}$./cu.m. for smoke and sulphur dioxide, and episodes in which daily figures exceeded 500 $\mu$ g./cu.m. were common for smoke (45 during 1964) and fairly common for sulphur dioxide (32 during 1964).

\section{Selection OF THE CHIIDREN}

The sample consisted of all infants in their first year at the selected schools living in the surrounding council estates. In the case of the heavily-industrialized Attercliffe area, no council housing was available and the sample of first year infants from the selected schools came from a defined area immediately surrounding the schools. The mean age of the children at the time of examination was 5 years 4.5 months for boys and 5 years 4.4 months for girls with age ranges of one year.

At this age smoking habits and the occupational environment, two factors which complicate adult studies, could be disregarded. It was hoped that the restriction of the study to children of local authority tenants would minimize socio-economic differences between the study areas; subsequent Tables show that this equality was not entirely achieved. As the housing estates were all well established, it is likely that most of these young children had lived all their lives in the one area, and that the effect of migration, which might be serious in an older population could be disregarded.

At the same time a sample of 10 to 11-year-old children was studied in the same areas; the findings among these older children will be the subject of another report.

\section{COLlection of the Data}

All the data for the study were collected during the summer terms of 1963, 1964, and 1965 with a view to minimizing absences and any effects of acute respiratory illnesses upon the pulmonary ventilatory measurements.

A questionnaire to parents was sent out and returned via the school; 2 or 3 weeks later the children were examined in school and in nearly all cases a parent was present, so that queries arising from the questionnaire could be checked.

Information collected from parents covered a history of measles, whooping cough, asthma, pneumonia, and bronchitis; whether the child suffered from a persistent or frequent cough, more than three colds a year, earache or ear discharge, sore throats or tonsillitis; and whether colds usually went to the child's chest.

Inquiries into the home background concerned the numbers and ages of other persons in the house and the presence of "bronchitics", the size of house, sharing of the subjects' bed and bedroom, and employment of parents.

The examination consisted of palpating for enlarged tonsillar lymph glands, observing the presence or absence of a muco-purulent nasal discharge after each child had blown his nose into a paper handkerchief, examination of the eardrums for scarring or perforation, and examination of the tonsils. In addition, the school nursing sister recorded each child's height and weight and a doctor recorded the forced expiratory volume (F.E.V.) to a timing of $0.75 \mathrm{sec}$. and the forced vital capacity (F.V.C.) using a Poulton spirometer.

\section{REsults}

\section{(1) SOCIO-ECONOMic Characteristics OF THE} SAMPLE

A total of 819 children was seen and their distribution by sex and area is shown in Table III (overleaf); 413 of these children came from the clean Greenhill area, 194 from the Longley area, 130 from the Park area, and 82 from the heavily-polluted Attercliffe area. 
TABLE III

NUMBER OF CHILDREN IN SURVEY

\begin{tabular}{c|c|c|c|c|c}
\hline Area & Greenhill & Longley & Park & Attercliffe & Total \\
\hline Boys & 211 & 89 & 59 & 38 & 397 \\
Girls & 202 & 105 & 71 & 44 & 422 \\
\hline Total & 413 & 194 & 130 & 82 & 819 \\
\hline
\end{tabular}

Examination of the social class of the fathers demonstrated considerable differences (Table IV). The highest proportion of semi-skilled and unskilled workers occurred in the Park area of council housing and not in the Attercliffe area of substandard Victorian housing as might have been expected. Greenhill, the council housing area with the least atmospheric pollution, had an excess of professional and intermediate classes and was deficient in semiskilled and unskilled classes.

TABLE IV

SOCIAL CLASS OF FATHERS, BY AREA (Percentages)

\begin{tabular}{|c|c|c|c|c|}
\hline Area & Greenhill & Longley & Park & Attercliffe \\
\hline $\begin{array}{l}\text { Professional and inter- } \\
\text { mediate (I and II) } \\
\text { Skilled (III) } \\
\text { Semi-skilled and unskilled } \\
\text { (IV and V) }\end{array}$ & $\begin{array}{r}6 \cdot 5 \\
74 \cdot 5 \\
19 \cdot 0\end{array}$ & $\begin{array}{r}3 \cdot 1 \\
67 \cdot 3 \\
29 \cdot 6\end{array}$ & $\begin{array}{r}1 \cdot 9 \\
52 \cdot 4 \\
45 \cdot 7\end{array}$ & $\begin{array}{r}2 \cdot 8 \\
64 \cdot 8 \\
32 \cdot 4\end{array}$ \\
\hline Total & $\begin{array}{l}352 \\
(=100 \\
\text { per cent. })\end{array}$ & $\begin{array}{c}162 \\
(=100 \\
\text { per cent. })\end{array}$ & $\begin{array}{l}105 \\
(=100 \\
\text { per cent. })\end{array}$ & $\begin{array}{l}71 \\
(=100 \\
\text { per cent. })\end{array}$ \\
\hline
\end{tabular}

The number of children in the house also differed by area, there being an increasing proportion of houses with three or more children and a decreasing proportion with one or two children, from Greenhill to Longley, to Park, to Attercliffe (Table V).

TABLE V

NUMBER OF CHILDREN IN THE HOUSE, BY AREA (Percentages)

\begin{tabular}{|c|c|c|c|c|c|c|c|}
\hline Area & .. & . & . & Greenhill & Longley & Park & Attercliffe \\
\hline $\begin{array}{l}\text { One } \\
\text { Two } \\
\text { Three or } r\end{array}$ & $\begin{array}{l}\ddot{ } \\
\text { more }\end{array}$ & $\begin{array}{l}. \\
\cdots \\
.\end{array}$ & $\begin{array}{l}\cdots \\
\cdots\end{array}$ & $\begin{array}{l}16 \cdot 5 \\
40 \cdot 2 \\
43 \cdot 3\end{array}$ & $\begin{array}{l}15 \cdot 3 \\
37 \cdot 7 \\
47 \cdot 0\end{array}$ & $\begin{array}{l}13 \cdot 9 \\
29 \cdot 5 \\
56 \cdot 6\end{array}$ & $\begin{array}{l}13 \cdot 6 \\
27 \cdot 2 \\
59 \cdot 2\end{array}$ \\
\hline Total & . & $\cdots$ & $\cdots$ & $\begin{array}{c}411 \\
(=100 \\
\text { per cent. })\end{array}$ & $\begin{array}{l}183 \\
(=100 \\
\text { per cent. })\end{array}$ & $\begin{array}{l}122 \\
(=100 \\
\text { per cent. })\end{array}$ & $\begin{array}{l}81 \\
(=100 \\
\text { per cent. })\end{array}$ \\
\hline
\end{tabular}

The number of persons in the subjects' bedroom showed a similar pattern, except that there was a considerable excess of sharing by three or more persons in Attercliffe. Probably this was due to the smaller number of usable bedrooms available in the Victorian terrace housing (Table VI).

The pattern of respiratory disease in each area could be influenced not only by the levels of atmospheric pollution but also by the socio-economic factors. In the next section, therefore, the contrasts between the areas will be examined first, and later
TABLE VI

PERSONS IN SUBJECTS' BEDROOM, BY AREA (Percentages)

\begin{tabular}{|c|c|c|c|c|c|c|c|}
\hline Area & . & . & .. & Greenhill & Longley & Park & Attercliffe \\
\hline $\begin{array}{l}\text { One } \\
\text { Two } \\
\text { Three or } n\end{array}$ & $\begin{array}{l}\cdots \\
\text { more }\end{array}$ & $\begin{array}{l}\cdots \\
\cdots \\
\cdots\end{array}$ & $\begin{array}{l}. \\
\cdots \\
\cdots\end{array}$ & $\begin{array}{l}36 \cdot 8 \\
48 \cdot 4 \\
14 \cdot 8\end{array}$ & $\begin{array}{l}27 \cdot 9 \\
42 \cdot 5 \\
29 \cdot 6\end{array}$ & $\begin{array}{l}23 \cdot 3 \\
49 \cdot 2 \\
27 \cdot 5\end{array}$ & $\begin{array}{l}14 \cdot 3 \\
41 \cdot 6 \\
44 \cdot 1\end{array}$ \\
\hline Total & . & . & . & $\begin{array}{l}364 \\
(=100 \\
\text { per cent. })\end{array}$ & $\begin{array}{l}179 \\
(=100 \\
\text { per cent. })\end{array}$ & $\begin{array}{l}120 \\
(=100 \\
\text { per cent. })\end{array}$ & $\underset{\text { per cent. })}{\stackrel{77}{=} 100}$ \\
\hline
\end{tabular}

sections will consider how far socio-economic differences could have contributed to these results. $\vec{\theta}$ (2) HISTORY AND CLINICAL EVIDENCE OF RESPIRATORY $\overrightarrow{\vec{\omega}}$
DISEASE BY AREA

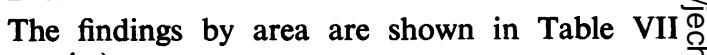
(opposite).

Muco-purulent nasal discharge was present in $8.4 \stackrel{\text {. }}{-}$ per cent. of the children and was over twice as com- $\vec{y}$ mon in Park and Attercliffe as in Greenhill and $\mathrm{O}$ Longley. The differences were significant $(P<0.001) . \stackrel{-}{.}$ It should be stressed that the assessments were made $\vec{C}$ during the summer terms so that the presence of a muco-purulent nasal discharge at this time was a fair indication of a chronic upper respiratory tract 2 infection.

A history of three or more colds yearly was ro ported in 40.0 per cent. of the children. There was 9 lower proportion in Greenhill (less than 35 per cent) than in the other three areas (about 45 per cent.) and this difference was significant $(P<0.01)$.

Scarred or perforated eardrums were seen in $\frac{0}{\mathrm{D}}$ 11.3 per cent. of the children. The assessment was $\stackrel{\circ}{\rightarrow}$ only possible in 759 of the 819 children $(92.7$ perô cent.) because wax in the auditory canal obscured the drums in a number of cases. The proportions of children in which an assessment could be made differed little by area (Greenhill 92.3 per cent., $\stackrel{\odot}{\circ}$ Longley 91.8 per cent., Park 96.2 per cent., Atter-? cliffe 91.5 per cent.), and it was considered unlikely윽 that comparison between the areas would be biased by the missing observations. The percentage of $\mathcal{O}$ children with scarred or perforated eardrums showed a trend from area to area, being lowest $(9.4$ per cent.) $)$ 을 in the least polluted area of Greenhill and rising in $>$ the progressively more polluted areas of Longley, Park, and Attercliffe to $10 \cdot 7,14 \cdot 4$, and $17 \cdot 3$ per cent. $N$ respectively. Although the trend was consistent, the differences between areas were not significant. 0

A history of a persistent or frequent cough was $\omega$ found in 30.6 per cent. of the children. The proportion with a positive history was over twice as higho in Attercliffe (50.0 per cent.) as in Greenhill (22.9ळ per cent.), the Longley and Park areas giving inter-? mediate figures of 36.1 and 34.6 per cent. respectively. 
TABLE VII

HISTORY AND CLINICAL EVIDENCE OF RESPIRATORY DISEASE, BY AREA (Percentages)

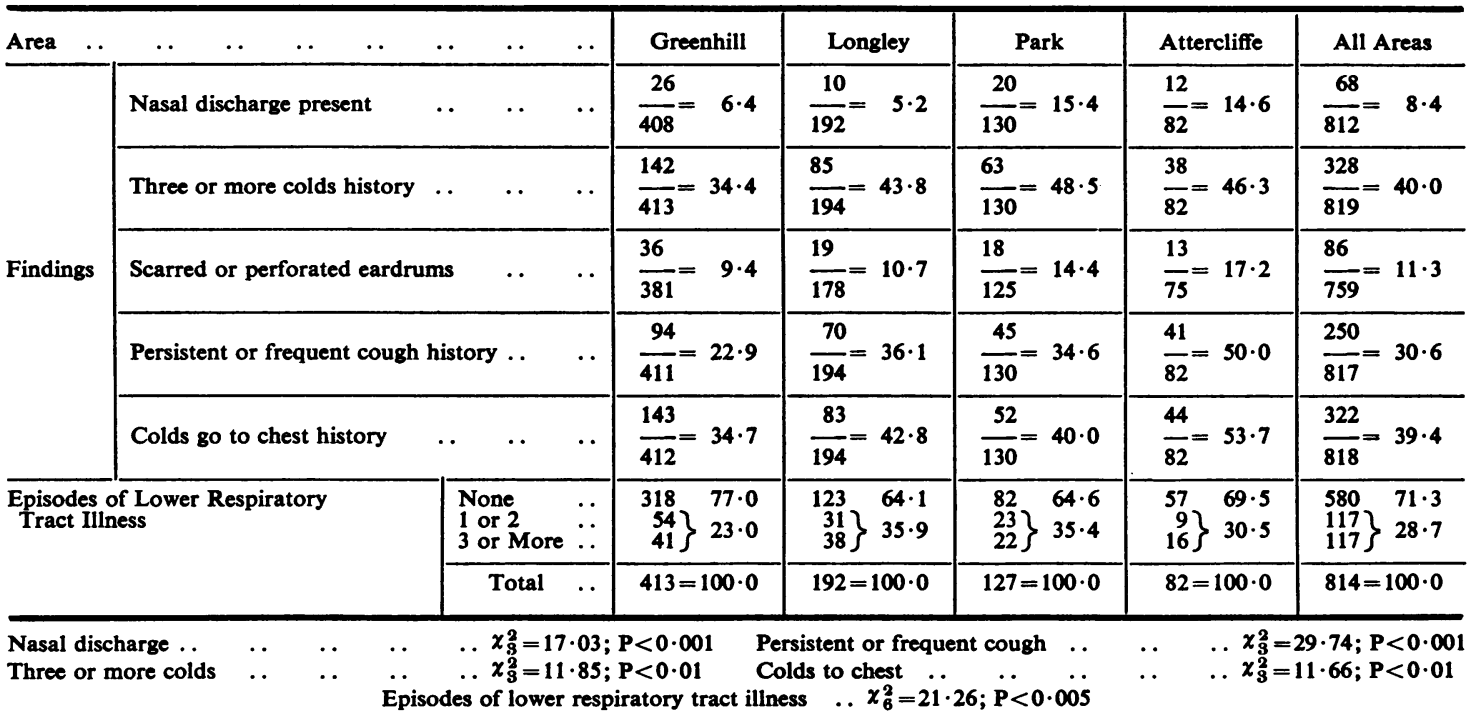

The differences between areas were significant $(\mathrm{P}<0.001)$.

A history of colds tending to go to the chest was given by 39.4 per cent. of the children. The pattern was similar to that of persistent or frequent cough, with extremes of 34.7 per cent. in Greenhill and 53.7 per cent. in Attercliffe; Longley and Park occupying an intermediate position. These differences were significant $(\mathrm{P}<0.01)$. A history of lower respiratory tract illness (pneu- VIII. monia or bronchitis) was found in 28.7 per cent. of the children. The rates in Longley, Park, and Attercliffe were very similar $(35 \cdot 9,35 \cdot 4$, and $30 \cdot 5$ per cent. respectively), but the rate in Greenhill was significantly lower $(P<0.005)$. This pattern was similar to that for a history of three or more colds per year.

(3) Respiratory Disease and Social Class

The findings by social class are shown in Table

TABLE VIII

HISTORY AND CLINICAL EVIDENCE OF RESPIRATORY DISEASE, BY SOCLAL CLASS (Percentages)

\begin{tabular}{|c|c|c|c|c|c|c|c|}
\hline Socio-economic Class & mic Class & . & . & I and II & III & IV and $V$ & All \\
\hline \multirow{5}{*}{ Findings } & Nasal discharge present & .. & $\cdots$ & $\frac{3}{32}=9.4$ & $\frac{40}{466}=8.6$ & $\frac{13}{185}=7 \cdot 0$ & $\frac{56}{683}=8 \cdot 2$ \\
\hline & \multicolumn{2}{|l|}{ Three or more colds history } & .. & $\frac{9}{32}=28 \cdot 1$ & $\frac{199}{472}=42 \cdot 2$ & $\frac{68}{190}=35.8$ & $\frac{276}{694}=39.8$ \\
\hline & \multicolumn{2}{|c|}{ Scarred or perforated eardrums .. } & $\cdots$ & $\frac{4}{31}=12 \cdot 9$ & $\frac{44}{429}=10 \cdot 3$ & $\frac{20}{175}=11 \cdot 4$ & $\frac{68}{635}=10 \cdot 7$ \\
\hline & \multicolumn{2}{|c|}{ Persistent or frequent cough history } & . & $\frac{5}{32}=15.6$ & $\frac{138}{470}=29 \cdot 4$ & $\frac{70}{186}=37 \cdot 6$ & $\frac{213}{688}=31 \cdot 0$ \\
\hline & Colds go to chest history & . & $\cdots$ & $\frac{12}{32}=37.5$ & $\frac{192}{472}=40 \cdot 7$ & $\frac{72}{185}=38.9$ & $\frac{276}{689}=40 \cdot 1$ \\
\hline \multirow{2}{*}{\multicolumn{2}{|c|}{$\begin{array}{l}\text { Episodes of Lower Respiratory } \\
\text { Tract Illness }\end{array}$}} & $\begin{array}{l}\text { None } \\
1 \text { or } 2 \\
3 \text { or More }\end{array}$ & & $\left.\begin{array}{r}25 \\
4 \\
3\end{array}\right\} 21 \cdot 9$ & $\left.\begin{array}{c}334 \\
71 \\
64\end{array}\right\} 28 \cdot 8$ & $\left.\begin{array}{c}121 \\
28 \\
36\end{array}\right\} 34 \cdot 6$ & $\left.\begin{array}{l}480 \\
103 \\
103\end{array}\right\} 30 \cdot 0$ \\
\hline & & Total & .. & 32 & 469 & 185 & 686 \\
\hline
\end{tabular}


The prevalence of muco-purulent nasal discharge, scarred or perforated eardrums, three or more colds yearly, and colds going to the chest appeared to be unaffected by social class. The differences found were irregular in pattern and not significant.

A history of persistent or frequent cough showed a clear trend, being least common in Classes I and II (15.6 per cent.), more common in Class III (29.4 per cent.), and most common in Classes IV and V (37.6 per cent.). These differences were significant $(\mathrm{P}<0.02)$, but a similar trend for the history of lower respiratory tract illness was not significant.

(4) Respiratory Disease AND Number of CHILdReN IN THE House

The findings by the number of children in the house are shown in Table IX.

Apart from scarred or perforated eardrums, none of the findings showed clear trends or significant differences. Scarred or perforated eardrums were rather more common ( 15.3 per cent.) amongst the subjects from households containing three or more children than from households containing one or two children in which the equivalent rates were 8.4 and 9.0 per cent. respectively $(P<0.05)$.

(5) Respiratory Disease and Number of Persons IN THE SUBJECTS' BEDROOM

The findings by the number of persons in the subjects' bedroom are shown in Table X (opposite).

The prevalence of muco-purulent nasal discharge showed a small but consistent rise as the degree of bedroom sharing increased. The differences were not significant.
Histories of three or more colds yearly, persistenteD or frequent cough, and colds going to the chesto showed irregular differences with the lowest percent -3 ages in children sharing with one other person. The? differences for persistent or frequent cough and colds going to the chest were significant $(P<0.05$ in each case).

Scarred or perforated eardrums were less common (7.9 per cent.) amongst children sleeping alone than amongst children sharing their bedrooms $(65 / 784=\varnothing$ 13.4 per cent.). Although this difference was nots significant, it did reflect the earlier finding that subjects from households containing three or more children showed a higher rate of scarred or perforatedw eardrums than subjects from households containing? fewer children, since two children are unlikely too share a bedroom unless there are three or more children in the family.

(6) INFLUENCE OF SOCIO-ECONOMIC FACTORS OND Area Differences in Respiratory Disease

In the Tables reviewed so far, it has appeared that

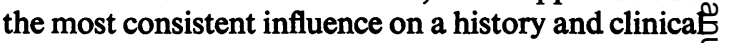
evidence of respiratory disease has been the arean in which the child lived. For all the items except nasal discharge, those in the cleanest area, Greenhill $\overrightarrow{5}$ gave the most favourable results, and even for this item the proportion was only just higher than in the next cleanest area, Longley. Attercliffe childrent living in the dirtiest area, had almost consistently the worst record. Although the trends mirrored they pollution levels somewhat irregularly, there seemsD to be a general association between the prevalence

TABLE IX

HISTORY AND CLINICAL EVIDENCE OF RESPIRATORY DISEASE, BY NUMBER OF CHILDREN IN HOUSE (Percentages)

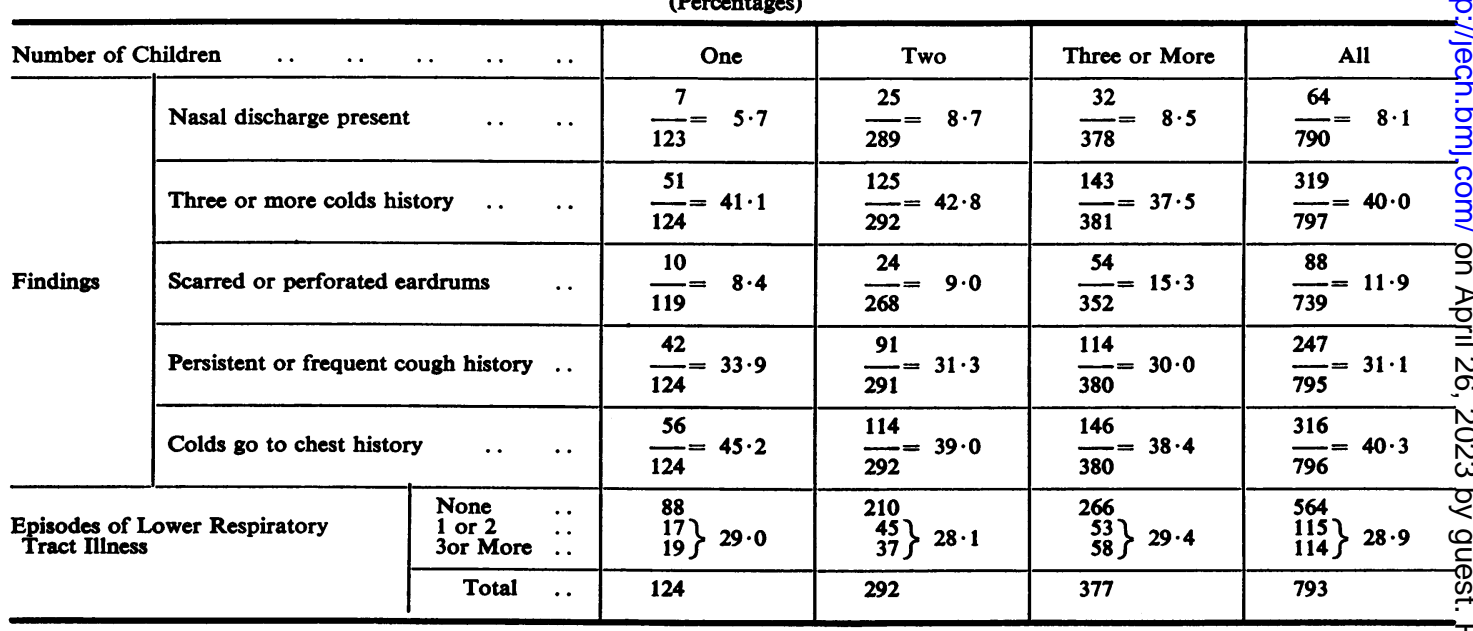


TABLE X

HISTORY AND CLINICAL EVIDENCE OF RESPIRATORY DISEASE, BY NUMBER OF PERSONS IN SUBJECTS' BEDROOM

\begin{tabular}{|c|c|c|c|c|c|c|c|}
\hline \multicolumn{3}{|c|}{ Persons in Bedroom } & .. & One & Two & \multirow{2}{*}{$\frac{\text { Three or More }}{\frac{18}{172}=10.5}$} & All \\
\hline \multirow{5}{*}{ Findings } & Nasal discharge present & .. & .. & $\frac{13}{218}=6.0$ & $\frac{28}{341}=8 \cdot 2$ & & $\frac{59}{731}=8 \cdot 1$ \\
\hline & \multicolumn{2}{|l|}{ Three or more colds history } & .. & $\frac{100}{223}=44 \cdot 8$ & $\frac{129}{343}=37.6$ & $\frac{74}{174}=42.5$ & $\frac{303}{740}=40.9$ \\
\hline & \multicolumn{2}{|c|}{ Scarred or perforated eardrums ... } & .. & $\frac{16}{202}=7.9$ & $\frac{42}{318}=13 \cdot 2$ & $\frac{23}{166}=13.9$ & $\frac{81}{686}=11 \cdot 8$ \\
\hline & \multicolumn{2}{|c|}{ Persistent or frequent cough history } & .. & $\frac{68}{223}=30.5$ & $\frac{95}{371}=27.9$ & $\frac{69}{174}=39 \cdot 7$ & $\frac{232}{738}=31 \cdot 4$ \\
\hline & Colds go to chest history & .. & .. & $\frac{95}{223}=42 \cdot 6$ & $\frac{122}{343}=36.6$ & $\frac{82}{173}=47 \cdot 4$ & $\frac{299}{739}=40.5$ \\
\hline \multirow{2}{*}{\multicolumn{2}{|c|}{$\begin{array}{l}\text { Episodes of Lower Respiratory } \\
\text { Tract Illness }\end{array}$}} & $\begin{array}{l}\text { None } \\
1 \text { or } 2 \\
3 \text { or More }\end{array}$ & $\because$. & $\left.\begin{array}{c}158 \\
35 \\
30\end{array}\right\} 29 \cdot 1$ & $\left.\begin{array}{r}244 \\
46 \\
51\end{array}\right\} 28 \cdot 4$ & $\left.\begin{array}{c}114 \\
29 \\
28\end{array}\right\} 33 \cdot 3$ & $\left.\begin{array}{l}516 \\
110 \\
109\end{array}\right\} 29 \cdot 8$ \\
\hline & & Total & .. & 223 & 341 & 171 & 735 \\
\hline
\end{tabular}

of upper and lower respiratory disease and air pollution levels. However, these cleaner areas are better off in their socio-economic conditions than the dirtier areas, and the possibility exists that the relationship with pollution is incidental and not contributory to the respiratory disease patterns.

Tables VIII, IX, and X show that the only socioeconomic factors having a regular and significant influence on disease in these children are:

(a) Social class with a history of persistent or frequent cough.

(b) Number of children in the house with scarred or perforated eardrums.

Regular but insignificant associations were found between:

(c) Social class and episodes of lower respiratory tract illness.

(d) Number of persons in the subjects' bedroom and nasal discharge and scarred or perforated eardrums.

An irregular significant association was found between:

(e) Number of persons in the subjects' bedroom and persistent or frequent cough and colds going to the chest.

The influence of all these associations on the area differences was examined. Table XI shows the most important of these, the effect of the social class distribution on the proportions of children with persistent cough in the different areas. The numbers are small in several cells of the Table but it is clear that within Social Classes III and IV and V the area difference remains, with the lowest proportion in Greenhill and the highest in Attercliffe $(P<0.02$ in both cases): with each area, however, the gradient by social class is neither regular nor significant.

TABLE XI

HISTORY OF PERSISTENT OR FREQUENT COUGH, BY AREA AND SOCIAL CLASS. (Percentages)

\begin{tabular}{|c|c|c|c|c|c|c|c|c|c|c|c|c|}
\hline Area .. & . & .. & . & . & .. & .. & . & Greenhill & Longley & Park & Attercliffe & All Areas \\
\hline \multirow{3}{*}{ Social Class . } & & \multirow{3}{*}{. } & I and II & & .. & . & . & $\frac{0}{23}=0.0$ & $\frac{3}{5}=60 \cdot 0$ & $\frac{1}{2}=50 \cdot 0$ & $\frac{1}{2}=50 \cdot 0$ & $\frac{5}{32}=15 \cdot 6$ \\
\hline & & & III & . & $\cdots$ & $\cdots$ & $\cdots$ & $\frac{63}{260}=24 \cdot 2$ & $\frac{37}{109}=33.9$ & $\frac{17}{55}=30 \cdot 9$ & $\frac{21}{46}=45 \cdot 7$ & $\frac{138}{470}=29 \cdot 4$ \\
\hline & & & IV and $V$ & & . & .. & . & $\frac{16}{67}=23.9$ & $\frac{19}{48}=39 \cdot 6$ & $\frac{21}{78}=43 \cdot 8$ & $\frac{14}{23}=60.9$ & $\frac{70}{186}=37 \cdot 6$ \\
\hline Total & .. & .. & .. & . & . & $\cdots$ & . & $\frac{79}{350}=22 \cdot 6$ & $\frac{59}{162}=36.4$ & $\frac{39}{105}=37 \cdot 1$ & $\frac{36}{71}=50 \cdot 7$ & $\frac{213}{688}=31 \cdot 0$ \\
\hline
\end{tabular}

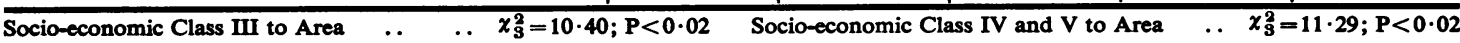


A similar pattern was found for the other associations of socio-economic factors and disease; namely, the area differences persisted under fixed socio-economic conditions, but the socio-economic differences were irregular and insignificant in individual areas.

\section{(7) Respiratory Measurement Findings}

Measurements of F.E.V.0.7s and F.V.C. were adjusted to permit direct comparison of children of varying height. The technique has been fully described in an earlier article (Lunn, 1965). Each child's measurements are expressed as ratios of the expected measurements for the child's standing height. The ratio has been recorded as a percentage, therefore the average child has an F.E.V.0.75 ratio or an F.V.C. ratio of 100 .

Distributions and means of the F.E.V.0.75 and F.V.C. ratios are shown by area in Tables XII and XIII respectively. The mean F.E.V.0.75 and F.V.C. ratios for Greenhill, Longley, and Park were very similar and were all close to the 100 per cent. level ranging from 99.8 to $100 \cdot 1$ for F.E.Vs and from 99.6 to 99.9 for F.V.Cs. The measurements for Attercliffe were considerably lower. The mean F.E.V.0.75 ratio for Attercliffe was 95.6 and differed from the next lowest mean reading (Longley, 99.8) at a 1 per cent. level of significance. The mean F.V.C. ratio for Attercliffe was 95.8 and differed from the next lowest mean reading (Greenhill, 99.6) at a 0.1 per cent. level of significance.

TABLE XII

DISTRIBUTION AND MEANS OF F.E.V.0.75 RATIOS, BY AREA

\begin{tabular}{|c|c|c|c|c|c|c|}
\hline Area & .. & $\begin{array}{c}\text { Green- } \\
\text { hill }\end{array}$ & Longley & Park & $\begin{array}{l}\text { Atter- } \\
\text { cliffe }\end{array}$ & $\begin{array}{c}\text { All } \\
\text { Areas }\end{array}$ \\
\hline \multirow{2}{*}{$\begin{array}{l}\text { F.E.V. } \\
\text { Ratio }\end{array}$} & \multirow{2}{*}{$\begin{array}{l}\text { Under } 80 \\
80- \\
100- \\
120 \text { and } \\
\text { Over } \\
\text { Total }\end{array}$} & $\begin{array}{r}26 \\
167 \\
153\end{array}$ & $\begin{array}{l}10 \\
73 \\
71\end{array}$ & $\begin{array}{l}10 \\
46 \\
45\end{array}$ & $\begin{array}{r}9 \\
38 \\
20\end{array}$ & $\begin{array}{r}55 \\
324 \\
289\end{array}$ \\
\hline & & $\begin{array}{r}31 \\
377\end{array}$ & $\begin{array}{r}10 \\
164\end{array}$ & $\begin{array}{r}10 \\
111\end{array}$ & $\begin{array}{r}4 \\
71\end{array}$ & $\begin{array}{r}55 \\
723\end{array}$ \\
\hline Mean & . & $100 \cdot 1$ & $99 \cdot 8$ & 99.9 & $95 \cdot 6$ & 99.6 \\
\hline
\end{tabular}

Attercliffe-Longley $\mathbf{P}<0.01$.

TABLE XIII

DISTRIBUTION AND MEANS OF F.V.C. RATIOS, BY AREA

\begin{tabular}{|c|c|c|c|c|c|c|}
\hline Area & . & $\begin{array}{c}\text { Green- } \\
\text { hill }\end{array}$ & Longley & Park & $\begin{array}{l}\text { Atter- } \\
\text { cliffe }\end{array}$ & $\begin{array}{c}\text { All } \\
\text { Areas }\end{array}$ \\
\hline \multirow{2}{*}{$\begin{array}{l}\text { F.V.C. } \\
\text { Ratio }\end{array}$} & \multirow{2}{*}{$\begin{array}{l}\text { Under } 80 \\
80- \\
100- \\
120 \text { and } \\
\text { Over } \\
\text { Total }\end{array}$} & $\begin{array}{r}22 \\
176 \\
153\end{array}$ & $\begin{array}{r}6 \\
74 \\
77\end{array}$ & $\begin{array}{r}6 \\
52 \\
47\end{array}$ & $\begin{array}{r}7 \\
41 \\
21\end{array}$ & $\begin{array}{r}41 \\
343 \\
298\end{array}$ \\
\hline & & $\begin{array}{r}26 \\
377\end{array}$ & $\begin{array}{r}7 \\
164\end{array}$ & 111 & 71 & $\begin{array}{r}41 \\
723\end{array}$ \\
\hline Mean & . & 99.6 & 99.9 & 99.9 & $95 \cdot 8$ & 99.4 \\
\hline
\end{tabular}

Atterclifie-Greenhill P<0.001.
Mean F.E.V.0.75 and F.V.C. ratios by social clase children in the house, and persons in the subjects bedroom are shown in Table XIV. The differences were insignificant.

\section{TABLE XIV}

MEAN F.E.V.0.75 AND F.V.C. RATIOS BY SOCIAL CLASS NUMBER OF CHILDREN IN HOUSE AND NUMBER OO

\begin{tabular}{|c|c|c|c|}
\hline & Mean Ratio & F.E.V. & F.V.C. \\
\hline Social Class & $\begin{array}{l}\text { I and II } \\
\text { III } \\
\text { IV and V }\end{array}$ & $\begin{array}{c}98 \cdot 6(28) \\
99 \cdot 3(418) \\
100 \cdot 5(163)\end{array}$ & $\begin{array}{l}97.5(28) \\
99.2(418)-1 \\
99.9(163)\end{array}$ \\
\hline $\begin{array}{l}\text { No. of Children } \\
\text { in house }\end{array}$ & $\begin{array}{l}1 \\
2 \\
3\end{array}$ or More & $\begin{array}{r}98 \cdot 3(111) \\
100 \cdot 3(263) \\
99 \cdot 3(329)\end{array}$ & $\begin{array}{r}101.4(111) \vec{\omega} \\
99.0(263) \omega \\
99.2(329)\end{array}$ \\
\hline $\begin{array}{l}\text { No. of Persons } \\
\text { in bedroom }\end{array}$ & $\begin{array}{l}1 \\
2 \\
3\end{array}$ or More & $\begin{array}{r}98 \cdot 6(199) \\
100 \cdot 5(307) \\
98 \cdot 7(146)\end{array}$ & $\begin{array}{l}99 \cdot 4(199) \stackrel{\mathrm{T}}{\mathrm{9}} \\
99 \cdot 0(307) \overline{\mathrm{T}} \\
99 \cdot 5(146) \mathrm{N}\end{array}$ \\
\hline
\end{tabular}

Figures in brackets indicate total number of children in each category

In theory, respiratory measurements could be affected by a history of persistent or frequent cough colds going to the chest, and episodes of pneumoni and bronchitis. These possibilities were investigated and the findings are shown in Tables XV and XVI (opposite).

A history of persistent or frequent cough givas associated significantly with a lowered man F.E.V.0.75 ratio $(\mathrm{P}<0.05)$ and the association $\bar{W}$ consistent within each area.

Similarly, a history of colds going to the chest w\$3 associated with a significantly lowered mea⿱i F.E.V.0.75 ratio $(\mathrm{P}<\mathbf{0 . 0 0 1 )}$ and once more the association was consistent within each area.

Children with no past history of lower respiratory tract illness had higher F.E.V.0.75 ratios than child ren with a history of one or two episodes of lower respiratory tract illness. These children in turn had higher F.E.V.0.75 ratios than those with a history of three or more such episodes. The differences we significant $(\mathrm{P}<0.001)$ and the differences between children with a negative and positive history of lower respiratory tract illness were consistent within each area.

The mean F.V.C. ratio findings were similar pattern to the mean F.E.V.0.75 ratio findings whem all areas were considered together (Table XVA) Namely, a history of persistent or frequent cough, colds going to the chest, or episodes of lowe respiratory tract illness was associated with reduced F.V.C. ratios. The reductions in F.V.C. ratio, however, were small and not significant, and examine tion of the data by separate areas showed a consiste reduction of F.V.C. ratio only in the case of children with past episodes of lower respiratory tract illness: 
TABLE XV

MEAN F.E.V.0.7s RATIOS, BY HISTORY OF PERSISTENT OR FREQUENT COUGH, COLDS GOING TO CHEST, AND EPISODES OF LOWER RESPIRATORY TRACT ILLNESS, BY AREA

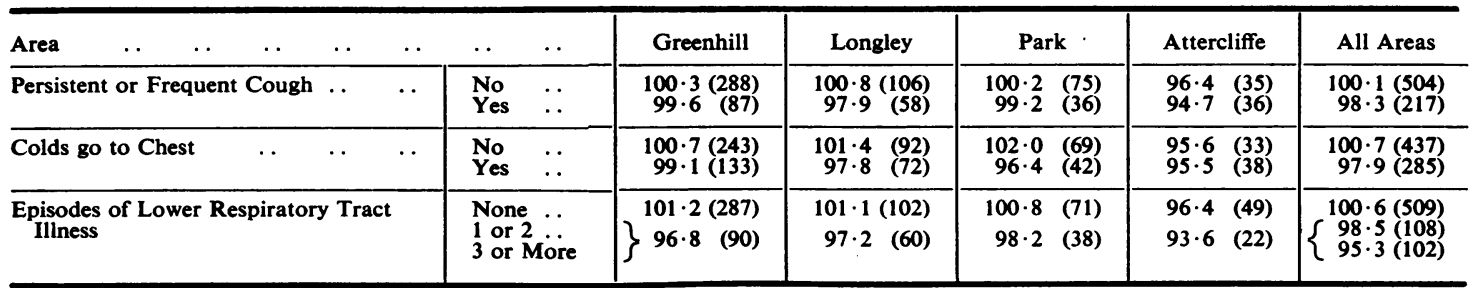

Figures in brackets indicate total number of children in each category.

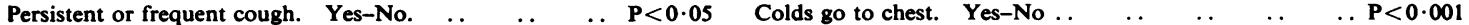
Episodes of lower respiratory tract illness .. None-1 or 2-3 or more $P<0.001$

TABLE XVI

MEAN F.V.C. RATIOS, BY HISTORY OF PERSISTENT OR FREQUENT COUGH, COLDS GOING TO CHEST, AND EPISODES OF LOWER RESPIRATORY TRACT ILLNESS, BY AREA

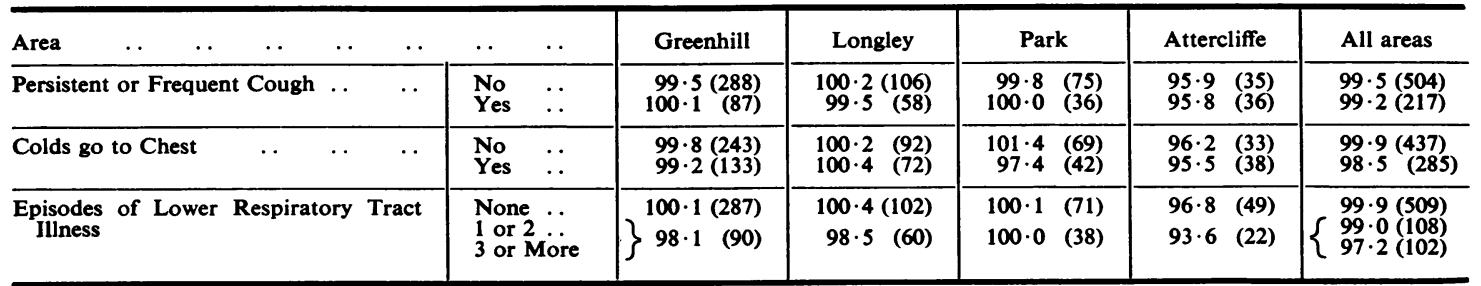

\section{Discussion}

The findings in this study suggest that chronic upper respiratory infections (as measured by muco-purulent nasal discharge, a history of three or more colds yearly, and scarred or perforated eardrums) are influenced by area rather than by social class, number of children in the house, or sharing of bedrooms. Similarly, lower respiratory tract illness (as measured by a history of persistent or frequent cough, colds going to the chest, or episodes of pneumonia and bronchitis) are more affected by area than by the socio-economic factors already mentioned. The major difference between the study areas was the level of atmospheric pollution and the severity of the pollution was reflected to a considerable extent in the upper and lower respiratory tract findings. In the absence of complicating factors such as employment, smoking habits, changes of address, and changing pollution levels over a long period of years, it is difficult to excuse atmospheric pollution as an important factor in the causation of the respiratory findings in these children.

So far as the lower respiratory tract findings are concerned, this study supports the picture previously described by Douglas and Waller (1966) but the upper respiratory tract findings show a relationship with pollution which was not apparent in the earlier study. A possible explanation lies in the different methods used to grade the children into pollution categories. In the case of the Sheffield children, the actual pollution measurements were known for the chosen areas, whereas in the earlier study the lack of pollution data necessitated a grading by coalconsumption categories. Although subsequent data have permitted mean values for smoke and sulphur dioxide to be ascribed to these categories, the variation within the categories must be considerable and may have influenced the results.

The respiratory measurement findings showed no association with area, social class, children in the house, and sharing of bedrooms, although Attercliffe, the area of highest pollution, showed reduced F.E.V.0.75 and F.V.C. ratios. On the other hand, very clear evidence of reduced F.E.V.0.75 ratios emerged where there was a past history of pneumonia and bronchitis, persistent or frequent cough, or colds going to the chest. It must be stressed that these findings relate to first year infant schoolchildren and that measurements were made during the summer term when pollution levels were low and acute respiratory infections few and far between. In other words, a pattern of respiratory disability had appeared at an early age and was sufficiently established to persist although the factors of pollution and infection were temporarily absent or at a low level. The findings underline the importance of an effective clean air policy and the importance of treating lower 
respiratory tract illnesses of young children early on and effectively.

\section{SUMMARY}

Data are presented on 819 infant schoolchildren living in areas of Sheffield with widely ranging air pollution levels. The majority of the children came from council housing estates and had lived in the same area for most of their lives.

Upper respiratory tract illnesses, measured in terms of muco-purulent nasal discharge and three or more colds yearly, showed an association with area which generally reflected the pollution levels. Illness was less common in the clean than in the dirty areas. Lower respiratory tract illnesses, measured in terms of persistent or frequent cough, colds going to the chest, and episodes of pneumonia and bronchitis, showed a similar pattern. In contrast to the area findings, socio-economic factors such as social class, number of children in the house, and sharing bedrooms appeared to have little influence upon respiratory illness amongst the children.

F.E.V. 0.75 and F.V.C. ratios were unaffected by socio-economic factors or by area, except for the most heavily-polluted district, Attercliffe, where a significant reduction was noted.

A past history of persistent or frequent cough, colds going to the chest, and pneumonia and bronchitis was associated in all areas with a reduction in the F.E.V.0.75 ratio. A similar but much weaker association occurred with the F.V.C. for the children as a whole but not in the individual areas.

The presence in infant schoolchildren of an association between atmospheric pollution and respiratory illness, and in turn an association between respiratory illness and impaired F.E.V.0.75 $(D$ measurements, underlines the importance of an effective clean air policy and of treating lower 3

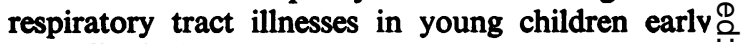
and effectively.

We wish to thank Dr Llywelyn Roberts, lately Principalo School Medical Officer, Dr C. H. Shaw, Principal Schoolo Medical Officer, and Dr E. G. M. Oates, Senior School $\overline{\bar{c}}$ Medical Officer, for their support of this project, and also $\widehat{\varnothing}$ the head teachers who received us into their schools and
gave us every assistance.

For the collection of data, we wish to thank Prof. J. K. $\vec{\circ}$ Page who gave valuable advice in the formative stages, Dr M. T. Lunn, Mrs J. Knowelden, Mrs C. H. Stuart- $\vec{\omega}$ Harris, Mrs M. Carpenter, Miss E. Dent, Chief School Nursing Sister, and the Nursing Sisters and Assistants of the Sheffield School Health Service who took part; also? Mr H. J. Aldous, Housing Manager, and members of his department. We also wish to thank Miss J. Hawley,Miss M. Beddard, and Mrs H. Silvester for the processing $\backslash$ of the data, and Miss J. Pickering and Miss C. Hartleyo for their secretarial and clerical assistance. Finally, wewish to thank the parents and the children themselves forc their enthusiastic co-operation.

This work has been aided by a Sheffield University Tuberculosis Research Fund Grant.

\section{REFERENCES}

Douglas, J. W. B., and Waller, R. E. (1966). Brit. J. prey soc. Med., $20,1$.

Fairbairn, A. S., and Reid, D. D. (1958). Ibid., 12, 94ב

Holland, W. W., and Reid, D. D. (1965). Lancet, 1, 445 . Lunn, J. E. (1965). Brit. J. prev. soc. Med., 19, 115.

Rosenbaum, S. (1961). Ibid., 15, 61.

Toyama, T., and Tomono, Y. (1961). Jap. J. Publ. Hlth, $\stackrel{\circ}{\stackrel{\complement}{\varrho}}$

8, 659.
Zeidberg, L. D., Prindle, R. A., and Landau, E. (1964). Amer. J. publ. Hith, 54, 85. 